\title{
Relationship Of Physical Activity, Diet, And Age Menarche With Age Menopause At Elderly Posyandu Working Area Puskesmas Pekauman Banjarmasin
}

\author{
Hariadi Widodo ${ }^{1}$ \\ ${ }^{1}$ Department of Nursing, STIKES Sari Mulia, Banjarmasin, Indonesia \\ *dedelianti27@gmail.com \\ Fadhiyah Noor Anisa ${ }^{2}$ \\ ${ }^{2}$ Academy of Midwifery Sari Mulia, Banjarmasin, Indonesia \\ fadhiya_noor_annisa@akbidsarimulia.ac.id \\ Dede Lianti ${ }^{3 *}$ \\ ${ }^{3}$ Department of Midwifery, STIKES Sari Mulia, Banjarmasin, Indonesia \\ dedelianti@gmail.com
}

\begin{abstract}
Objective: To know the relationship of physical activity, diet and menarche age with age of menopause at Posyandu elderly working area Puskesmas Pekauman Banjarmasin.

Methods: The research used quantitative analytic with cross sectional approach. The population is women aged 45-59 years in Posyandu elderly working area Puskesmas Pekauman. Samples were post-menopausal women aged 45-59 at Posyandu elderly working area Pekauman Community Health Center April 2017 amounted to 47 people, taken by accidental sampling technique. Data were analyzed using Chi-Square test with $95 \%$ confidence level.

Results: $51 \%$ of respondents of normal menopausal age, $61.70 \%$ of respondents of normal menarche age, $78.70 \%$ of respondents not eating well, $53.20 \%$ of respondents of moderate physical activity. There was a relationship between menarche age and age of menopause $(p=0.012<\alpha 0.05)$. There was a relationship between physical activity and age of menopause $(p=0.029<\alpha 0.05)$. There was no association between diet and age of menopause $(p=0,524>\alpha 0.05)$.

Conclusion: Age of menarche and physical activity associated with age of menopause. Women are expected to prepare themselves ahead of menopause by doing enough physical activity.
\end{abstract}

Keywords: Age of Menarche, Age of Menopause, Diet, Physical Activity.

\section{INTRODUCTION}

Fear of menopause always comes to every woman at the productive age. Early menopause that occurs during the productive age describes the health status and becomes a sign of aging. The decrease or absence of estrogen means it can change energy levels, memory, bone health, hormones, urinary and heart health. The average menopause occurs at the age of 51 years or within the range of 45-55 years. The average age of female menopause in Australia is 51-52 years. There 
are more than 4 million women in the United Kingdom aged between 45-51 years who will experience a menopausal transition [1] and The Association of UK Dietitians (2016) said menopause occurs between the ages of 45-55 years. In Indonesia in 2000, the average age of menopause at the age of 47 years and in 2010 obtained an average age of menopause 45 years [2].

Menopause that occurs naturally or induced will be called early menopause if it occurs at age $\leq 40$ years. Early menopause increases the risk of early chronic illness in life [3]. One of the factors associated with menopause is the pattern of life. Pattern of life in question is the state of nutrition or diet, physical activity or exercise and smoking habits [4]. Research Fransiska (2013) mentioned factors that affect menopause is diet, exercise and smoking behavior [5]. The greatest factors affecting consecutively the age of menopause are exercise, income, number of children, cigarette consumption, menarche, and marital status [2]. Efforts that can be done to maintain health during menopause is by giving hormone therapy, a healthy lifestyle such as eating nutritious foods, exercising and drinking water multiply. Applying a balanced diet, regular exercise, not smoking, multiply the rest can slow the occurrence of menopause.

The number of postmenopausal women in Asia by 2025 will reach 373 million people [2], while The North American Society (2016) mentions that by 2025 the number of menopausal women is expected to increase to 1.1 billion worldwide. By 2020 it is estimated that the number of women living at the age of menopause is 30.3 million people [2].

Field observation data conducted in January 2017 at one posyandu work area Puskesmas Pekauman 10 mothers said that he had not experienced menstruation since 3 years ago and there have been since 9 years ago. Of the 10 mothers, mothers who have experienced menopausal symptoms are under the age of 50 years old at the age of 44 years as many as 2 mothers, 47 years as many as 2 mothers and 46 years of 1 mother and 5 mothers at the age above 50 years ie 51 years as many as 1 mother , 52 years as many as 2 mothers, and 53 years as many as 2 mothers. Ten mothers said they have a habit of eating 3 meals a day with rice, vegetables, fish and fruit, three meals a day with rice and fish, and irregular eating habits. Of the 10 mothers there are 4 mothers who say have street habit 2-3 times a week and 6 mothers say rarely do morning walk. The 10 mothers also said they had first menstruation since the age of 9 years, 10 years, 11 years, 12 years, 13 years, and 15 years. From some questions asked during the preliminary study it can be concluded that there are mothers who experience menopause symptoms at a faster age, the mother's diet is still there that is not good and there are mothers who experienced first menstruation at the age of under 12 years or early menarche experience. 
Women who will enter menopause must be able to prepare themselves physically and psychologically. The health of menopausal women is influenced by the lifestyle of women during the time before menopause. Based on the description above, researchers are interested to examine the relationship of physical activity, diet, and menarche age with age of menopause at posyandu elderly working area Puskesmas Pekauman.

\section{METHOD AND PROCEDURES}

This research was conducted at Posyandu Lansia working area Puskesmas Pekauman Banjarmasin. The objectives of this study were mothers aged $45-59$ years who visited the Posyandu Lansia working area Puskesmas Pekauman Banjarmasin and have experienced menopause. This research uses quantitative analytic research design with cross sectional design. The population in this study were all women of elderly (45-59 years old) who followed the posyandu elderly activities as many as 168 mothers in October to December 2016. The sample of this study amounted to 47 people with sampling using accidental sampling technique. Data were analyzed using Chi-Square test with 95\% confidence level.

\section{RESULTS}

Table 1. Frequency distribution of menopausal age

\begin{tabular}{ccc}
\hline $\begin{array}{c}\text { Age category } \\
\text { Menopause }\end{array}$ & Frequency & $\begin{array}{c}\text { Percent } \\
(\%)\end{array}$ \\
\hline Normal & 24 & 51 \\
\hline Abnormal & 23 & 49 \\
\hline Total & 47 & $100 \%$ \\
\hline
\end{tabular}

Based on table 1, menopausal age was found to be the normal age of menopause, ie 24 respondents (51\%) of 47 respondents.

Table 2. Frequency distribution of diet

\begin{tabular}{ccc}
\hline Diet Category & Frequency & Percent (\%) \\
\hline Good & 10 & $21,30 \%$ \\
\hline Less & 37 & $78,70 \%$ \\
\hline Total & 47 & $100 \%$ \\
\hline
\end{tabular}

Based on table 2 found the most eating pattern is not good diet, that is 37 respondents $(78,70 \%)$ from 47 respondents.

Table 3. Distribution of Frequency of physical activity

\begin{tabular}{ccc}
\hline $\begin{array}{l}\text { Category } \\
\text { Physical } \\
\text { Activity }\end{array}$ & Frequency & $\begin{array}{l}\text { Percentage } \\
(\%)\end{array}$ \\
\hline Low & 9 & $19,10 \%$ \\
\hline Midle & 25 & $53,20 \%$ \\
\hline High & 13 & $27,70 \%$ \\
\hline Total & 47 & $100 \%$ \\
\hline
\end{tabular}

Based on table 3 obtained the most physical activity is a moderate physical activity, ie 25 respondents $(53.20 \%)$ of 47 respondents.

Table 4. Analysis of menarche age relationship with age of menopause

\begin{tabular}{|c|c|c|c|c|c|c|}
\hline \multirow{3}{*}{$\begin{array}{c}\text { Age } \\
\text { category } \\
\text { Menarche }\end{array}$} & \multicolumn{6}{|c|}{ Age of menopause } \\
\hline & \multicolumn{2}{|c|}{ Abnormal } & \multicolumn{2}{|c|}{ Normal } & \multicolumn{2}{|c|}{ Total } \\
\hline & $\mathrm{N}$ & $\%$ & $\mathrm{~N}$ & $\%$ & $\mathrm{~N}$ & $\%$ \\
\hline $\begin{array}{c}\text { Abnormal } \\
<12 \text { and }> \\
15\end{array}$ & 13 & $27,7 \%$ & 5 & $10,6 \%$ & 18 & $38,3 \%$ \\
\hline $\begin{array}{c}\text { Normal } \\
12-15 \\
\end{array}$ & 10 & $21,3 \%$ & 19 & $40,4 \%$ & 29 & $61,7 \%$ \\
\hline Total & 23 & $49 \%$ & 24 & $51 \%$ & 47 & $100 \%$ \\
\hline
\end{tabular}


Based on the above table obtained the results of Chi Square test analysis with a value of 0.012 , if the probability $\mathrm{p}<\alpha(\alpha=$ 0.05), then Ho is rejected and $\mathrm{Ha}$ accepted, it shows there is a relationship between menarche age with age menopause.

Table 5. Analysis of dietary relationships with age of menopause

\begin{tabular}{lcccccc}
\multirow{2}{*}{$\begin{array}{c}\text { Diet } \\
\text { Category }\end{array}$} & \multicolumn{6}{c}{ Age of Menopause } \\
\cline { 2 - 7 } & \multicolumn{2}{c}{ Abnormal } & \multicolumn{2}{c}{ Normal } & \multicolumn{2}{c}{ Total } \\
\cline { 2 - 7 } & $\mathrm{N}$ & $\%$ & $\mathrm{~N}$ & $\%$ & $\mathrm{~N}$ & $\%$ \\
\hline Less & 19 & $40,40 \%$ & 18 & $38,3 \%$ & 37 & $78,7 \%$ \\
\hline Good & 4 & $8,50 \%$ & 6 & $12,8 \%$ & 10 & $21,3 \%$ \\
\hline Total & 23 & $48,90 \%$ & 24 & $51,10 \%$ & 47 & $100 \%$ \\
\hline \multicolumn{6}{c}{$\mathrm{p}=0,524$} \\
\hline
\end{tabular}

Based on the above table obtained the results of Chi Square test analysis with a value of 0.524 , if the probability $p>\alpha(\alpha=0.05)$, then Ho accepted and Ha rejected, this shows no association between diet with age of menopause.

Table 6. Analysis of the relationship of physical activity with age of menopause

\begin{tabular}{ccccccc}
\hline \multirow{2}{*}{$\begin{array}{c}\text { Physical } \\
\text { Activity }\end{array}$} & \multicolumn{5}{c}{ Age of Menopause } \\
\cline { 2 - 7 } Category & Abnormal & \multicolumn{2}{c}{ Normal } & \multicolumn{2}{c}{ Total } \\
\cline { 2 - 7 } & $\mathrm{N}$ & $\%$ & $\mathrm{~N}$ & $\%$ & $\mathrm{~N}$ & $\%$ \\
\hline Rendah & 5 & $10,6 \%$ & 4 & $8,50 \%$ & 9 & $19,1 \%$ \\
\hline Sedang & 8 & $17 \%$ & 17 & $36,2 \%$ & 25 & $53,2 \%$ \\
\hline Tinggi & 10 & $21,3 \%$ & 3 & $6,4 \%$ & 13 & $27,7 \%$ \\
\hline Jumlah & 23 & $48,9 \%$ & 24 & $51,1 \%$ & 47 & $100 \%$ \\
\hline \multicolumn{7}{c}{$\mathrm{p}=0,029$} \\
\hline
\end{tabular}

Based on the above table obtained the results of Chi Square test analysis with a value of 0.029 , if the probability $p<\alpha(\alpha=$ 0.05), then Ho is rejected and Ha accepted, it shows there is a relationship between physical activity with age menopause.

\section{DISCUSSION}

The results of this study are in line with the results Sepduwiana (2016), age of menopause in the research was found that women on average experienced menopause at age 47.6 years. The equation of the results of this study indicates that the age of menopause is included into the menopause quickly and can be categorized into abnormal menopausal age. The age difference of menopause can be influenced by other factors such as menstrual cycle, long menstrual cycle will slow down the process of egg release, while shortening menstrual cycles will accelerate the production of egg cells so that the eggs quickly reduced. The acceleration of age of menopause will disrupt the productive life of a woman, therefore women must prepare to enter the menopause such as diet and physical activities [6].

The results of the study conducted at posyandu elderly working area of puskesmas Pekauman showed that respondents mostly experienced normal menarche with average menarche at age of 12.83 years and can be categorized into normal menarche age. The results of this study in accordance with research conducted Rika (2012) that the average menarche occurred at the age of 14.56 years. The results of this study have similarities with the Sepduwiana study (2016), menarche average occurred at the age of 13.1 years. Both studies show that the average teenager has a normal age of menarche [7].

Normal menarche age will occur when the production of the hormone estrogen in the body goes well, so it can stimulate the maturation of follicles de graaf to produce eggs (ovulation). Menarche does not rule out can also occur at a younger age, this is influenced by some things like the five senses. The influence of the senses affects the rapidity of menarche age because the puberty inhibitor nucleus passes the sensor received from the audiovisual. Therefore, to prevent the occurrence of menarhe age is not normal then it needs to be considered in terms of health in the body such as maintaining a diet 
and reduce the senses that affect the acceleration of the age of menarche. A teenager who experiences late menarche age also needs attention, health checks need to be done to determine the health status, such as hormone production in the body or the presence of diseases that can hinder the production of reproductive hormones.

Diet is a variety of information that gives an idea of the variety and amount of food eaten every day by one person [8]. There are two things that are contained in a good diet, namely a healthy diet and eating patterns. Healthy foods are foods that contain nutrients in it [9]. Healthy foods are foods that contain sources of carbohydrates, proteins, fats, vitamins, minerals, fiber and water. A good or healthy diet is a variety of foods, not only contain one type of food, eat regularly morning, noon and night, eat enough as needed to try to gain weight not excessive, and pay attention to water consumption 6-8 glasses per day.

Based on the research it is found that respondents have various kinds of work, such as lifting rattan, traveling traders and selling at home, in addition to activities outside the home, respondents also do homework. The average number of respondent's physical activity is 3,100 . Physical activity conducted by dominant respondents of moderate physical activity. Moderate and high physical activity can affect the production of the hormone estrogen. Therefore, women should be encouraged to pay attention to the level of physical activity. Adequate physical activity is very beneficial for the body's health and hormone production. Physical activity can be measured by individual individuals such as using an IPAQ questionnaire to assess the level of physical activity. A woman is expected to perform enough physical activity and exercise in order to have selfpreparedness in the face of menopause.

The relationship obtained from bivariate analysis found that respondents who experienced abnormal menarche age will experience abnormal menopausal age, while the normal age menarche mother will experience normal menoapuse age. The results of this study have similarities with the theory of Manuaba (2010), women who experience pretoking or early puberty will experience menopause more quickly. Menarche's rapid age results in faster oocyte degeneration, leading to ovarian atresia and malfunction [10]. The results of this study in accordance with the research Li et al (2012), women who menarche early will quickly experience menopause [11].

Women who have preterm or early puberty will experience menopause more quickly. Menarche's rapid age results in faster oocyte degeneration, causing ovarian atresia 
and malfunction. Changes in the menstrual cycle will begin to occur when a woman has entered a period of perimenopause. Premenopausal women will experience irregular menstrual cycles accompanied by physiological changes. In the perimenopause period there will be a decrease in ovarian function associated with decreased hormone estradiol and androgen hormone production. The irregular menstrual cycle will change to the absence of menstruation for 12 consecutive months indicating a woman has entered the menopausal stage [10].

Based on the results of studies of abnormal menopausal age found in many respondents who experienced menarche not normal. Researchers argue that the faster a woman experiences menarche the faster menopause. Menopausal age is faster due to ovarian function earlier, so the number of eggs expenditure will also be faster. The acceleration of menopausal age can also be affected by short menstrual cycles (polimenorrhea) or shortened follicular phases that cause the follicles to be ready for ovulation. Ovulation that occurs in shortening cycles can lead to rapid reduction in the number of eggs. Therefore, women who have a history of menarche at $<12$ years and $>15$ years of age can prepare the quality of self by maintaining fitness and body health that can be done with diligent exercise and diet.

Adequate nutritional fulfillment will greatly assist in inhibiting the negative effects of menopause on brain performance, preventing dry skin, and other diseases. The aging process results in decreased activity, so the need for caloric metabolism also decreases [12].

Eating nuts affects the age of menopause. Women who often consume nuts will have 1.6 years of age menopause slower than women who rarely consume nuts [6]. Mulyati et al (2006) also mentioned that consuming isoflavones affects the start of one's menopause. Phytoestrogens contained in isoflavones contain compounds similar to estrogen, which can slow the age of menopause and reduce menopausal symptoms [13].

The results of this study are not in accordance with research Fransiska (2013) which states that the diet associated with age menopause [5]. Based on the results of the study found that mothers who experience abnormal menopausal age have bad diet, but there is no relationship between diet and age of menopause. 
However, this study has similarities with Puspitasari (2016) research that food intake has no relationship with age of menopause. The absence of this association can be due to irregular menstrual cycles or prolonged menstrual cycles due to the influence of high physical activity that causes the follicular attenuation or degeneration [14].

Physical activity will affect the hormone levels in the body, the most influential physical activity is heavy or high physical activity. Severe or high physical activity will affect hormone levels in the body during activity or after heavy or high physical activity. Severe or high physical activity will affect the production of hormones such as decreased production of estradiol, progesterone, prolactin, Folicle Stimulating Hormone (FSH) and Luteinizing Hormone (LH) (Jurkowski et al, 1978 in Puspitasari, 2016). Severe physical activity will affect hormone levels resulting in irregularity of the menstrual cycle [14]. Women who have high physical activity will experience menopause more quickly, high physical activity can accelerate the age of menopause because it can reduce the work of ovaries in stimulating estrogen hormone release and increase sex hormone globulin that result in acceleration of age menopause.

The results of this study are in line with the theory and several studies that say that there is a relationship between physical activits with age of menopause. Researchers argue that high physical activity leads to irregularity in hormone production in the body, although there is no clear pathophysiology regarding the relationship of physical activity and hormone levels in the body. The disorder of hormone production is influenced by excessive body workload. Excessive body workloads make the hypothalamus function impaired and cause disturbance of Gonadotropin Releasing Hormone (GnRH) secretion. GnRH has a relationship with the production of the hormone estrogen, so that if $\mathrm{GnRH}$ secretion is inhibited it will also reduce the production of the hormone estrogen. The low production of the hormone estrogen will inhibit the follicle phase and cause menstruation to be stopped. Therefore, women are advised not to excessive physical activity, in addition to risk of menopause quickly, excessive physical activity can also increase the incidence of osteoporosis at the age above 30 years. In order to improve the quality of life required adequate physical activity, exercise and a good diet. 


\section{REFERENCES}

[1]. Women's Health Concern Fact Sheet. The Menopause [Internet] 2015. [diunduh 2017 Jan 12].Tersedia pada: https://www.womens-health concern.org.

[2]. Herawati, Rika.2012.Faktor-faktor yang berhubungan dengan Usia Menopause di Empat Posyandu Lansia Wilayah Kerja Puskesmas Rambah Kabupaten Rokan Hulu.J.Maternal dan Neonatal [Internet]. [diunduh 2016 Des 2];1(1).1-8.Tersedia pada:http://download.portalgaruda.org

[3]. Mishra. Early Menarche, Nulliparity and the risk for premature and early natural menopause. 2017. [Internet]. [diunduh 2017 Jan 9]; 1-8.Tersedia pada: https://www.ncbi.nlm.nih.gov.

[4]. Winkjosastro, Hanafi. Ilmu Kandungan. Jakarta:Bina Pustaka Sarwono Prawirohardjo. 2007.

[5]. Fransiska, Aggrey Swanny. Hubungan Pola Hidup dan Usia Ibu Saat Kehamilan Pertama dengan Terjadinya Menopause di Wilayah Kerja Puskesmas Polonia Medan [Internet].[diunduh 2017 Jan 20].Tersedia pada: http://repository.usu.ac.id.

[6].Sepduwiana, Heny. Usia Menopause pada Wanita di Wilayah Kerja Puskesmas Rambah Kabupaten Rokan Hulu.J.Maternity and Neonatal[Internet]. 2016. [diunduh 2017 Mar 16];2(2).145-153.Tersedia pada: http://e-journal.upp.ac.id.
[7]. Rika. Strategi Memperlambat Usia Menopause di Posyandu Lansia Kabupaten Rokan Hulu.J.Maternity dan Neonatal [Internet] 2012. [diunduh 2017 Jan 9]; 1(4).142-160.Tersedia pada: http://download.portalgaruda.org.

[8]. Basfrida, Rika dan Cut Yuniwati. Hubungan Pola Makan dan Olahraga Dengan Kesiapan Menghadapi Menopause Di Wilayah Kerja Puskesmas Blang Bintang Kabupaten Aceh Besar [Internet] 2014. [diunduh pada 2017 Jan 20].Tersedia pada: http://nasuwakesaceh.ac.id

[9]. Badriah, Dewi Laelatul. Gizi Dalam Kesehatan Reproduksi.Bandung:Refika Aditama. 2014.

[10]. Manuaba, Ida Bagus. Memahami Kesehatan Reproduksi Wanita.Jakarta: 2009.

[11]. Li. Factors Associated wtih The Age of Natural Menopause and Menopausal Symptoms in Chinese Women. [Internet].[diunduh $2017 \quad$ Mar 16].73.354-360.Tersedia pada: http://dx.doi.org/10.1016/j.maturitas.20 12.09.008

[12]. Proverawati, Atikah dan Emy Sulistyawati. Menopause dan Sindrome Premenopause.Yogyakarta:Nuha Medika. 2010.

[13]. Mulyati, Sri. Konsumsi Isoplavon Berhubungan dengan Usia Mulai Menopause.J.Universa

Medicina.[Internte]. 2006. [diunduh 
2017 Mar 16].25(4).148-154.Tersedia

pada: http://univmed.org

[14]. Puspitasari, Caselia Ajeng. Analisis

Pola Makan Dan Aktivitas Fisik

Terhadap Usia Menopause Di Kota

Bogor.[Internet] 2016. [diunduh 2017

Mar 29].Tersedia pada:

http://repository.ipb.ac.id. 